\title{
Acute Kidney Injury Caused by Bothrops Snake Venom
}

\author{
Lívia Rodrigues Sgrignolli Glória Elisa Florido Mendes Carla Patricia Carlos \\ Emmanuel A. Burdmann \\ Renal Physiopathology Laboratory and Division of Nephrology, Department of Medicine, São José do Rio Preto \\ Medical School, FAMERP, São José do Rio Preto, Brazil
}

\section{Key Words}

Acute renal failure $\cdot$ Acute kidney injury - Acute tubular necrosis $\cdot$ Snake venom $\cdot$ Bothrops

\begin{abstract}
Medically important venomous snakes in Latin America belong to the genus Bothrops, Crotalus, Lachesis and Micrurus. The Bothrops genus is responsible for the majority of accidents. The WHO globally estimates $2,500,000$ poisonous snakebites and 125,000 deaths annually. In its last report in 2001, the Brazilian Ministry of Health accounted 359 deaths due to snakebites, of which the Bothrops genus was responsible for 185. Snake venoms cause local and systemic damage, including acute kidney injury, which is the most important cause of death among patients surviving the early effects of envenoming by the Crotalus and Bothrops genuses. Venom-induced acute kidney injury is a frequent complication of Bothrops snakebite, carrying relevant morbidity and mortality.

Copyright $\odot 2011$ S. Karger AG, Basel
\end{abstract}

\section{Introduction}

José de Anchieta, an important Jesuit leader in colonial Brazil, had already referred to the variety of snakes in the new territory in his letter to the Portuguese Crown dating from 1560, recording for the first time an accident by these animals. During the colonial period the reports on accidents and deaths caused by poisonous snakes were scarce, which were found only on death certificates or even in personal dairy notes [1].

In the early 20th century, in 1901, ophidism was introduced as a scientific approach. At that time, Vital Brasil carried out the first epidemiological study about snakebites in the state of São Paulo, Brazil, and produced the first anti-venom available for human use. An organized data collection on venomous snakebites was made through a specialized journal, 'Boletins para Observação de Accidentes Ophidicos' (Ophidic Accidents Observation Bulletin), which provided official information about venomous snakebites and was published in Brazil for nearly 50 years [2]. Subsequently, the information collected developed into detailed studies, including both patient profiles and a survey on the areas where the highest number of accidents occurred. Meanwhile, special attention was drawn to studies assessing venom-induced cell damage. In fact, snake venoms are extremely complex substances. They have proteic and non-proteic fractions, and may produce local changes, such as acute inflammatory activity, edema, ecchymosis, blisters and necrosis, and systemic changes, such as hemorrhage, blood pressure alteration, neurotoxicity, hemolysis, rhabdomyolysis and acute kidney injury (AKI). Renal injury is the leading cause of death among patients surviving the ear-

\section{KARGER}

Fax +4161306 1234 E-Mail karger@karger.ch www.karger.com

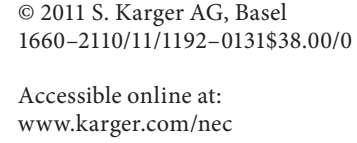

Emmanuel A. Burdmann

Av. Dr. Eneas de Carvalho Aguiar

$2557^{\circ}$ andar, sala $711 \mathrm{~F}$

São Paulo, SP 05403-000 (Brazil)

Tel. +55 113069 7684, E-Mail burdmann@usp.br 
ly effects of venom, and the most frequent renal histological injury found in venom-induced AKI is acute tubular necrosis $[1,3-6]$.

\section{Official Data on Accidents by Venomous Snakes}

The WHO globally estimates $2,500,000$ poisonous snakebites and 125,000 related deaths annually $[6,7]$. The Brazilian Ministry of Health's information on snake accidents covering the period from January 1990 to December 1993 [8] accounted for 81,611 snakebite accidents notified. These numbers mean an accident annual average of around 20,000 and an incidence coefficient of 13.5 per 100,000 inhabitants. Among these accidents, 65,911 were caused by venomous snakes. The highest number of occurrences was in the south and southeastern regions, probably due to their larger populations as well as their better organized public health and information system, allowing a more efficient data collection. On the other hand, the precarious access to health services in the north and northeastern regions is likely related to undernotification of accidents in those areas.

\section{Seasonal Incidence of Accidents}

Bothrops snakes are active in the night and prey during this time. Conversely, they are ectothermic reptiles and several biological processes as moving, digesting, sperm and egg cell production and embryo evolution are much more effective during the daytime due to warmer temperatures.

Ophidic accidents are related to climate factors suitable to soil preparation, planting and harvesting, when there are larger numbers of farm workers in the fields. In the south, southeastern and central-western regions, a higher incidence occurs between September and March. In the northeastern region, the highest incidence happens from January to May, while in the northern part of the country, occurrences take place throughout the year. These data are consistent with the snakes' liveliest activity during the hottest time of the year in each region $[1,8,9]$.

\section{Snake Genus}

Venomous snakes produce a toxic substance and inoculate it through a specialized apparatus. In snakes, envenoming is made through their hollow fangs which communicate with the venom-producing glandules. Clinically relevant venomous snakes in Latin America belong to the genus Bothrops, Crotalus, Lachesis and Micrurus $[6,10]$. The Bothrops genus is responsible for the majority of accidents. In Brazil, 65,911 out of 81,611 snakebite notifications were related to identified venomous snakes, and 59,619 (73.1\%) were caused by Bothrops genus snakes [8]. This larger prevalence is probably due to the vast and abundant geographic distribution and the aggressive behavior of these snakes $[1,2,6,8,9,11,12]$.

The Bothrops genus comprises over 30 species and subspecies spread out from the South of Mexico to Argentina and some Caribbean Islands. The most important species are Bothrops asper, Bothrops atrox and Bothrops jararaca. Interestingly, most Bothrops species are found in large numbers all over Latin and South America, while others are limited to a specific region, like the Bothrops insulinaris on Ilha da Queimada Grande, on the São Paulo state coast [1].

\section{Victim Profile}

A 30-year-old male farm worker arrives at an emergency service after having been bitten by a $B$. jararaca in the foot about $2 \mathrm{~h}$ earlier. This episode, so common nowadays, could have been written by Vital Brasil over 100 years ago. In fact, several studies have shown that the ophidic accident epidemiological profile has suffered few changes. 15- to 49-year-old male farm workers remain the most common victims, and feet and legs are the most affected sites [13, 14].

\section{Bothropic Accident Clinical Picture}

Snake venoms are composed of over 20 different components whose functions and interactions have not been entirely studied. 90-95\% of a snake venom net weight is composed of proteins (enzymes, non-enzyme toxins and non-toxic proteins). The non-proteic fraction is made up of carbohydrates, lipids, metals, biogenic amines, free amino acids and nucleotides $[1,6,8,9]$. The bothropic venom varies in its composition among the same species from different geographic regions, due to dietetic availability, and even in the same animal, depending on its age $[1,9,15-20]$. Despite venom variability, some basic actions are universal to all Bothrops species. 


\section{Local Manifestations}

Venom inoculation may occur via the subcutaneous or intramuscular route. Fang perforations may be single or even invisible. Site bleeding is common. Local pain which is induced by bradykinin and histamine, venom biogenic amines, is usually immediate. Early development of edema is frequent. It is usually tense and lilaceous, due to subcutaneous bleeding caused by small peptides and phospholipase $A_{2}$. The venom causes hemolysis, platelet aggregation, myonecrosis, vascular endothelium rupture and extracellular matrix component degradation $[1,6,8,9,21-23]$. In up to $24 \mathrm{~h}$, the whole limb may be impaired due to extracellular leaking. Infections such as abscess and cellulite may occur, due to contamination by the snake's oral bacterial flora $[8,9]$. Tissue necrosis caused by venom proteolytic action associated to vascular injury is a feared complication, which might be worsened by tourniquet use and treatment delay. Compartmental syndrome caused by the inflammatory and hemorrhagic processes in the injured area is unusual, demands rapid medical intervention when it occurs and makes patient management particularly difficult. Intense pain, paresthesia, cyanoses and temperature changes may occur as a result of the nervous-vascular bundle compression by the edema present in the affected area $[1,8,9]$.

\section{Systemic Manifestations}

Hemorrhagic manifestations such as gingival bleeding, microscopic hematuria, purpura and recent wound bleeding are frequent. Macroscopic hematuria, hemoptysis, epistaxis, conjunctival bleeding, hematemesis and central nervous system hemorrhage have been reported $[6,8,9,24]$. Shock and hypotension have been described following the bite $[6,8,14,23]$. Kidney injury is a frequent complication, causing high morbidity and mortality $[1,6$, $9,11,12,24-36]$.

Hemorrhage results from venom action causing coagulant system activation and intravascular fibrin formation. Such an action, known as 'thrombin-type coagulant action', is not neutralized by heparin. The final result is fibrinogen consumption and subsequent non-clotting. The venom, when activating factor $\mathrm{X}$, also consumes the factors V, VII and platelets causing capillary microthrombi formation, which contribute to the AKI genesis $[1,8,9,14,21,22]$. Bothrops venom also has high esterases activity. These proteases are responsible for hemorrhagic manifestations and kinin release $[1,8,9,21]$.
Table 1. Snakebite severity and treatment classification

\begin{tabular}{llll}
\hline & Mild & Moderate & Severe \\
\hline $\begin{array}{l}\text { Site manifestations: pain, } \\
\text { edema, ecchymosis }\end{array}$ & $\begin{array}{l}\text { absent or } \\
\text { discrete }\end{array}$ & evident & intense \\
\hline $\begin{array}{l}\text { Systemic manifestations: } \\
\text { serious hemorrhage, } \\
\text { shock, anuria }\end{array}$ & absent & absent & present \\
\hline $\begin{array}{llll}\text { Clotting time (CT) } & \text { normal or } & \text { normal or } & \text { normal or } \\
\text { altered } & \text { altered }\end{array}$ \\
\hline $\begin{array}{l}\text { Anti-venom therapy } \\
\text { (quantity of ampoules) }\end{array}$ & $2-4$ & $4-8$ & $8-12$ \\
\hline Route & IV & IV & IV \\
\hline
\end{tabular}

Normal CT: up to $10 \mathrm{~min}$, prolonged CT: from 10 to $30 \mathrm{~min}$, non-clotting CT: $>30 \mathrm{~min}$.

Data from the manual on diagnosis and treatment of accidents caused by poisonous snakes, Brazilian Ministry of Health, 2001.

\section{Treatment}

The specific and early anti-venom application is essential and decisive, considering that a fast specific treatment represents an extremely important positive prognostic factor. The accident classification under mild, moderate or severe is based on the patient's clinical status which determines the proper serum therapy proposed by Vital Brasil more than a century ago (table 1). Monitoring of blood pressure, respiratory condition, cardiac rate and adequate hydration should be performed. Attention to bite site injury and systemic bleeding is of high importance for treatment success $[1,4,8,9,12-14,37-41]$.

\section{Bothrops Venom-Induced AKI}

AKI, characterized by oliguria and serum creatinine increase, has been described to develop early after a $\mathrm{Bo}$ throps bite and may be severe requiring dialysis $[1,6,11$, $13,14,23-35]$. Data from retrospective series reported an AKI prevalence of 1.4-38\%, depending on the species [11, $14,26,29-35]$. It is the leading cause of lethality among patients surviving the early effects of the venom $[2,6,12$, $14,25]$, with mortality ranging from 13 to $19 \%[25,27,28$, 35]. Published data suggest that the patient's age and body surface area, the snake's age, amount of inoculated ven$\mathrm{om}$, bite site and the time elapsed until anti-venom treatment all influence AKI prevalence. Children under 10 
years of age have been shown to be more likely to develop complications $[1,4-6]$.

Besides the classical variables involved in AKI genesis, such as dehydration and hypotension, baseline diseases such as ischemic coronary artery disease, hypertension, diabetes, previous nephropathies, tobacco and alcohol use could be present, making these patients more vulnerable to the effects of snake venom.

The mechanisms of Bothrops venom-induced AKI have been attributed to the venom's direct action on the kidney, to its hypotensive effect, myoglobinuria, hemoglobinuria and to glomerular microthrombi deposit. Most of the available information on the mechanisms involved in AKI development after Bothrops snakebite comes from experimental studies [3, 4, 42-50]. Bothrops venom undergoes renal elimination. Bothrops alternatus venom has been detected in renal tissue $30 \mathrm{~min}$ after and in urine $3 \mathrm{~h}$ after intravenous inoculation in rats [49]. $B$. jararaca venom injection in rats caused AKI characterized by decreases in urinary output, glomerular filtration rate, renal plasma flow, and by an increase in renal vascular resistance [3]. The venom induces hemolysis and serum fibrinogen consumption. Kidney histology showed fibrin microthrombi deposits in the glomerular capillary [3], which has also been observed in recent studies on $\mathrm{Bo}$ throps neuwiedii venom [47]. Similar results have been found following intraperitoneal infusion of bothropic venom in rats [48]. Recent studies have observed a direct Bothrops venom-induced tubular and glomerular injury $[4,42,43,50]$. Bothrops moojeni's venom fractions studied in isolated kidney preparations promoted increased renal vascular resistance and urinary volume, glomerular filtration rate and renal perfusion flow decreases [45]. Acute tubular necrosis is the most frequent histological finding in AKI following a bothropic accident, but cortical necrosis, acute interstitial nephritis and glomerular alterations have also been described [3-6, 36].

Considering the high chance of developing kidney impairment after Bothrops snakebite, the immediate care must include patient's adequate hydration, aiming at a maximum renal protection. However, the most important treatment to prevent AKI is early and specific antivenom application at the recommended doses. In an experimental study on bothropic venom-induced AKI, de Castro et al. [4] demonstrated optimal kidney protection only when the venom and anti-venom were given simultaneously. In a prospective clinical study on Crotalus snakebite, a time longer than $2 \mathrm{~h}$ for anti-venom administration has been identified as an independent factor for AKI development [51]. Data available on dialysis treat- ment for Bothrops venom-induced AKI are very scarce. Either peritoneal treatment or hemodialysis have been used in $33-75 \%$ of the cases described $[25,28,52]$.

\section{Anti-Venom Treatment}

The conventional option for venomous snakebite treatment is the anti-venom produced from horse antibodies (produced in Brazil by the Instituto Butantan, Fundação Ezequiel Dias, and the Instituto Vital Brazil). However, this anti-venom is not considered ideal since it does not prevent local damages caused by the snake ven$\mathrm{om}$, it can induce hypersensitivity reactions and is sometimes difficult to find in remote areas [4, 13, 23, 53-56].

Da Silva et al. [55] have evaluated the capacity of serum preincubated with Bothrops jararacussu and B. jararaca venom in antagonizing venom-induced myonecrosis and hemorrhage in rats. They have found that preincubation with $B$. jararacussu venom was able to antagonize 40$95 \%$ of the venom myotoxicity and that the same procedure with $B$. jararaca venom antagonized $70-95 \%$ of the hemorrhagic activity of the venom. Theoretically, such a protocol might be useful in risk exposition situations or as a preventive therapy for people living in densely populated Bothrops areas.

Other authors have investigated marsupial serum application as a treatment against Bothrops erythromelas venom [57]. They concluded that marsupial serum features venom-neutralizing properties against hemorrhagic, myonecrotic, hyperalgesic and edematogenic effects of the venom. Didelphis marsupialis serum was also able to inhibit venom-induced effects in an isolated kidney preparation [57], representing a promising choice for venomous snakebite treatment.

Brazilian researchers have recently assessed the effects of a regional popular medicine against snake venom which is commonly used in the central region to treat snakebites $[58,59]$. They evaluated the effect of the administration of Schizolobium parahyba (Fabaceae) infusion and its fractions against the pharmacological and toxic activity of Bothrops venom in rats. This native plant from the Brazilian forest, popularly known as guapuruvú, was effective in protecting against some of the $B$. alternatus and $B$. moojeni venom-induced enzymatic and biological activities. Animal lethality was reduced to zero and the venom hemolytic, hemorrhagic and coagulation system effects were attenuated $[58,59]$. Studies aiming at Brazilian forest phytotherapy are a sustainable research choice. This new 'ancient' approach would meet both spe- 
cies preservation goals and cost-effectiveness, considering that animals would not be harmed and medicinal plants could be cultivated in different environments. Barone et al. [60] obtained partial renal protection using simvastatin and lipoic acid in a model of $B$. jararaca venom-induced AKI.

\section{Conclusions}

Clinical and experimental data clearly show that the bothropic venom leads to AKI, which is a major cause of death following snakebite accidents. Several educational and preventive actions should be taken in order to protect farm workers, who are the main victims of such acci- dents. The adverse effects of tourniquet use should be clarified, the 'homemade' formula limitations pointed out and, furthermore, the need for ready expert treatment should be remarked. Above all, the lyophilic antivenom should be made available in remote areas, and health agents should be trained to spread information as well as treatment routines which would both help and educate in case of snakebite accidents.

\section{Acknowledgement}

E.A.B. is partially supported by grants from the São Paulo Research Foundation (FAPESP) and National Council for Scientific and Technological Development (CNPq), Brazil.

\section{References}

1 Cardoso JLC, França FOS, Wen FH, Málaque CMS, Haddad V Jr: Animais peçonhentos no Brasil, biologia, clínica e terapêutica dos acidentes. São Paulo, Sarvier, 2003.

$\checkmark 2$ Bochner R, Struchiner CJ: Epidemiologia dos acidentes ofídicos nos últimos 100 anos no Brasil: uma revisão [Snake bite epidemiology in the last 100 years in Brazil: a review]. Cad Saude Publica 2003;19:7-16.

-3 Burdmann EA, Woronik V, Prado EB, Abdulkader RC, Saldanha LB, Barreto OC, Marcondes M: Snakebite-induced acute renal failure: an experimental model. Am J Trop Med Hyg 1993;48:82-88.

$\checkmark 4$ De Castro I, Burdmann EA, Seguro AC, Yu L: Bothrops venom induces tubular injury: role for lipid peroxidation and prevention by antivenom. Toxicon 2004;43:833-839.

5 Burdmann EA, Cais A, Vidal ED: IRA nefrotóxica: animais peçonhentos; in Schor N, Boim MA, Fernandes O (eds): Insuficiência Renal Aguda: Fisiopatologia, Clínica e Tratamento. São Paulo, Sarvier, 1997, pp 135-141.

6 Pinho FM, Yu L, Burdmann EA: Snakebiteinduced acute kidney injury in Latin America. Semin Nephrol 2008;28:354-362.

7 Chippaux, JP: Snake-bites: appraisal of the global situation. Bull World Health Organ 1998;76:515-524.

8 Ministério da Saúde (Brasil). Manual de Diagnóstico e Tratamento por Animais Peçonhentos, ed 2. Brasília, Fundação Nacional da Saúde, 2001.

9 Barraviera B: Venenos: Aspectos clínicos e terapêuticos dos acidentes por animais peçonhentos. Rio de Janeiro, Editora de publicações biomédicas, 1999.

10 Instituto Butantan (Internet). São Paulo, Instituto Butantan: Acidentes por animais peçonhentos: primeiros socorros (www.butantan.gov.br/perguntas.htm).
11 Ribeiro LA, Jorge MT: Acidentes por serpentes do gênero Bothrops: série de 3.139 casos [Bites by snakes in the genus Bothrops: a series of 3,139 cases]. Rev Soc Bras Med Trop 1997;30:475-480.

12 Ribeiro LA, Albuquerque MJ, Pires de Campos VAF, Katz G, Takaoka NY, Lebrão ML, Jorge MT: Óbitos por serpentes peçonhentas no Estado de São Paulo: avaliação de 43 casos, 1988/93 [Deaths caused by venomous snakes in the State of São Paulo: evaluation of 43 cases from 1988 to 1993]. Rev Ass Med Brasil 1998;44:312-318.

13 Cruz LS, Vargas R, Lopes AA: Snakebite envenomation and death in the developing world. Ethn Dis 2009;19(suppl 1):42-46.

14 Otero-Patiño R: Epidemiological, clinical and therapeutic aspects of Bothrops asper bites. Toxicon 2009;54:998-1011.

15 Ribeiro LA, Jorge MT: Epidemiologia e quadro clínico dos acidentes por serpentes Bothrops jararaca adultas e filhotes [Epidemiology and clinical picture of accidents by adult and young snakes Bothrops jararaca]. Rev Inst Med Trop 1990;32:436-442.

16 Perrone MAL, Villarroel MS, Furtado MFD Estudo comparativo entre os venenos de serpentes do Gênero Bothrops, procedentes do Estado de São Paulo e do Estado do Paraná com algumas espécies morfologicamente duvidosas. Mem Inst Butantan 1989;51:2532.

17 Oliveira RB, Ribeiro LA, Jorge MT: Fatores associados a incoagulabilidade sangüínea no envenenamento por serpentes do gênero $\mathrm{Bo}$ throps [Risk factors associated with coagulation abnormalities in Bothrops envenoming]. Rev Soc Bras Med Trop 2003;36:657-663.
18 Tan NH, Ponnudurai G: A comparative study of the biological properties of some venoms of snakes of the genus Bothrops (American lance-headed viper). Comp Biochem Physiol 1991;100:361-365.

19 Ferreira ML, Moura-da-Silva AM, França FO, Cardoso JL, Mota I: Toxic activities of venoms from nine Bothrops species and their correlation with lethality and necrosis. Toxicon 1992;30:1603-1608.

20 Queiroz GP, Pessoa LA, Portaro FC, Furtado Mde F, Tambourgi DV: Interspecific variation in venom composition and toxicity of Brazilian snakes from Bothrops genus. Toxicon 2008;52:842-851.

21 Netto CC: Estudo imunoquímico do veneno de Bothrops jararacussu, Lacerda 1884 e identificação de moléculas biomarcadas como ferramenta para o desenvolvimento de diagnóstico; thesis. Rio de Janeiro, Instituto Oswaldo Cruz, 2007, p 109.

22 Hawgood BJ, Rocha e Silva, M: Snake venom, bradykinin and the rise of autopharmacology. Toxicon 1997;35:1569-1580

23 Gutiérrez JM, Escalante T, Rucavado A: Experimental pathophysiology of systemic alterations induced by Bothrops asper snake venom. Toxicon 2009;54:976-987.

$\checkmark 24$ Pinho FMO, Burdmann EA: Fatal cerebral hemorrhage and acute renal failure after young Bothrops jararacussu snake bite. Renal Fail 2001;23:269-277.

25 Amaral CF, de Rezende NA, da Silva OA, Ribeiro MM, Magalhães RA, dos Reis RJ, Carneiro JG, Castro JR: Insuficiência renal aguda secundária a acidentes ofídicos botrópico e crotálico. Análise de 63 casos [Acute kidney failure secondary to ophidian bothropic and crotalid accidents. Analysis of 63 cases]. Rev Inst Med Trop 1986;28:220-227. 
26 Pinto RNL, Souza LCS, Silva AM, Pereira LIA, Andrade JG: Estudo clínico-epidemiológico de 774 casos de acidentes ofídicos. Rev Soc Bras Med Trop 1987;20(suppl):56.

27 Silva AO, Lopez M, Godoy P: Intensive care unit treatment of acute renal failure following snakebite. Am J Trop Med Hyg 1979;28: 401-407.

28 Vêncio D: Estudo do ofidismo em Goiás: comprometimento da função renal. Rev Goiana Med 1988;34:95-116.

29 Cupo P, Azevedo-Marques MM, Hering SE, Menezes JB: Acidentes ofídicos: análise de 102 casos; in XXI Congresso da Sociedade Brasileira de Medicina Tropical (livro de resumos), São Paulo 1985, pp 23-24.

30 Queiroz LP, Moritz RD: Acidente botrópico em Florianópolis. Arq Catarinenses Med 1989; 18:163-166.

31 Kouyoumdjian JA, Polizelli C, Lobo SMA: Acidentes ofídicos causados por Bothrops moojeni na Região de São José do Rio PretoSP. Arq Bras Med 1990;64:167-171.

- 32 Nishioka AS, Silveira PV: A clinical and epidemiological study of 292 cases of lanceheaded viper bite in a Brazilian teaching hospital. Am J Trop Med Hyg 1992;47:805-810.

33 Rodriguez AA, Uzcategui W, Azuaje R, Aguilar I, Giron ME: A clinical and epidemiological analysis of accidental bites by snakes of the genus Bothrops in Venezuela. Rev Cubana Med Trop 2000;52:90-94.

-34 Bucaretchi F, Herrera SRF, Hyslop S, Bcarat ECE, Vieira RJ: Snakebites by Bothrops spp. in children in Campinas, São Paulo, Brazil. Rev Inst Med Trop S Paulo 2001;43:329-333.

-35 Otero R, Gutiérrez J, Beatriz Mesa M, Duque E, Rodríguez O, Luis Arango J, Gómez F, Toro A, Cano F, María Rodríguez L, Caro E, Martínez J, Cornejo W, Mariano Gómez L, Luis Uribe F, Cárdenas S, Núñez V, Díaz A: Complications of Bothrops, Porthidium, and Bothriechis snakebites in Colombia. A clinical and epidemiological study of 39 cases attended in a university hospital. Toxicon 2002;40:1107-1114.

-36 Amaral CFS, Da Silva AO, Godoy P, Miranda D: Renal cortical necrosis following Bothrops jararaca and $B$. jararacussu snake bite. Toxicon 1985;23:877-885.

37 Jorge MT, Ribeiro LA: Dose do soro (antiveneno) no tratamento do envenenamento por serpentes peçonhentas do gênero Bothrops Antivenom serum doses in the treatment of poisoning by a venomous snake of the genus Bothrops]. Rev Ass Med Brasil 1997;43:7476.

- 38 Saraiva P, Rojas E, Escalante T, Arce V, Chaves E, Velásquez R, Lamonte B, Rojas G, Gutiérrez JM: The venom of Bothrops asper from Guatemala: toxic activities and neutralization by antivenoms. Toxicon 2001;39: 401-405.
39 Boechat ALR, Paiva CS, França FO, dos Santos MC: Heparin-antivenom association: differential neutralization effectiveness in Bothrops atrox and Bothrops erythromelas envenoming. Rev Inst Med Trop 2001;43:714.

40 Camey KU, Velarde DT, Sanches EF: Pharmacological characterization and neutralization of the venoms used in the production of bothropic antivenom in Brazil. Toxicon 2002;40:501-509.

41 Smalligan R, Cole J, Brito N, Laing GD, Mertz BL, Manock S, Maudlin J, Quist B, Holland G, Nelson S, Lalloo DG, Rivadeneira G, Barragan ME, Dolley D, Eddleston M, Warrell DA, Theakston RD: Crotaline snake bite in the Ecuadorian Amazon: randomized double-blind comparative trial of three South American polyspecific antivenoms. BMJ 2004;329:1129.

42 Boer-Lima PA, Gontijo JAR, Cruz-Höfling MA: Bothrops moojeni snake venom-induced renal glomeruli changes in rat. Am J Trop Med Hyg 2002;67:217-222.

43 Boer-Lima PA, Gontijo JAR, Cruz-Höfling MA: Histologic and functional renal alterations caused by Bothrops moojeni snake venom in rats. Am J Trop Med Hyg 1999;61:698706.

44 Havt A, Fontanels MC, Monteiro HAS: The renal effects of Bothrops jararacussu venom and the role of PLA2 and PAF blockers. Toxicon 2001;39:1841-1846.

45 Barbosa PSF, Havt A, Facó PEG, Sousa TM, Bezerra ISAM, Fonteneles MC, Toyama MH, Marangoni S, Novello JC, Monteiro HSA Renal toxicity of Bothrops moojeni snake venom and its main miotoxins. Toxicon 2002;40:1247-1435.

46 Monteiro HAS, Fonteneles MC: The effect of Bothrops jararaca venom on rat kidney after short-term exposure: preliminary results. Pharmacol Toxicol 1999;85:198-200.

47 Koscinczuk P, Borda JT, Maruñak S, de Perez OA, De Coppo NM: Daño renal em ratas inducido por veneno de Bothrops neuwiedii diporus de Argentina [Renal injury in rats poisoned by venom of Bothrops neuwiedii diporus from Argentina]. Medicina (Buenos Aires) 2004;64:320-324.

48 Rezende NA, Amaral CFS, Bambirra EA, Lachatt JJ, Coimbra TM: Functional and histopathological renal changes induced in rats by Bothrops jararaca venom. Braz J Med Biol Res 1999;22:407-416.

49 Mello SM, Linardi A, Rennó AL, Tarsitano CA, Pereira EM, Hyslop S: Renal kinetics of Bothrops alternatus (Urutu) snake venom in rats. Toxicon 2010;55:470-480.

50 Nascimento JM, Franchi GC Jr, Nowill AE Collares-Buzato CB, Hyslop S: Cytoskeletal rearrangement and cell death induced by $B o$ throps alternatus snake venom in cultured Madin-Darby canine kidney cells. Biochem Cell Biol 2007;85:591-605.
51 Pinho FM, Zanetta DM, Burdmann EA: Acute renal failure after Crotalus durissus snakebite: a prospective survey on 100 patients. Kidney Int 2005;67:659-667.

52 Santos MFL, Farani MC, Rocha PN: Insuficiência renal aguda em acidentes ofídicos por Bothrops sp. e Crotalus sp.: revisão e análise crítica da literatura [Acute kidney injury in Bothrops sp. and Crotalus sp. envenomation: critical review of the literature]. J Bras Nefrol 2009;31:132

53 Battellino C, Piazza R, Silva AMM, Cury Y, Farsky SHP: Assessment of bothropic antivenom therapy on microcirculatory effects induced by Bothrops jararaca snake venom. Toxicon 2003;41:583-593.

54 Camey KU, Velarde DT, Sanchez EF: Pharmacological characterization and neutralization of the venoms used in the production of bothropic antivenom in Brazil. Toxicon 2002;4:501-509.

-55 Da Silva NMV, Arruda EZ, Murakami YLB, Moraes RAM, El-Kik CZ, Tomaz MA, Fernandes FFA, Oliveira CZ, Soares AM, Giglio JR, Melo PA: Evolution of three Brazilian antivenom ability to antagonize myonecrosis and hemorrhage induced by Bothrops snake venom in mouse model. Toxicon 2007;50: 196-205.

56 Gutiérrez JM, Lomonte B, León G, Rucavado A, Chaves F, Angulo Y: Trends in snakebite envenomation therapy: scientific, technological and public health considerations. Curr Pharm Des 2007;13:2935-2950.

57 Martins AMC, Sousa FCM, Barbosa PSF, Toyama MH, Toyama DO, Aprígio CC, Queirós MGR, Guarnieri MC, Havt A, Menezes DB, Fonteneles MC, Monteiro HSA: Action of anti-bothropic factor isolated from Didelphis marsupialis on renal effects of Bothrops erythromelas venom. Toxicon 2005;46:595-599.

-58 Vale LH, Mendes MM, Hamaguchi A, Soares AM, Rodrigues VM, Homsi-Brandeburgo MI: Neutralization of pharmacological and toxic activities of Bothrops snake venoms by Schizolobium parahyba (Fabaceae) aqueous extract and its fractions. Basic Clin Pharmacol Toxicol 2008;103:104-107.

-59 Mendes MM, Oliveira CF, Lopes DS, Vale LH, Alcântara TM, Izidoro LF, Hamaguchi A, Homsi-Brandeburgo MI, Soares AM, Rodrigues VM: Anti-snake venom properties of Schizolobium parahyba (Caesalpinoideae) aqueous leaves extract. Phytother Res 2008; 22:859-866.

60 Barone JM, Alponti RF, Frezzatti R, Zambotti-Villela L, Silveira PF: Differential efficiency of simvastatin and lipoic acid treatments on Bothrops jararaca envenomation-induced acute kidney injury in mice. Toxicon 2011;57: $148-156$. 


\section{Editorial Comment}

Meguid El Nahas, Sheffield

The review by Sgrignolli and colleagues highlights the issue of Bothrops snakebite nephrotoxicity with emphasis on Brazil. Envenoming by snakebites is an important public health concern in tropical and subtropical regions. According to the WHO, in excess of 20,000 occur annually due to snakebites. Consequently, snakebites were added by the WHO in 2009 to the list of neglected tropical diseases. Whilst Brazil and Latin America are commonly affected, the highest numbers of envenoming are estimated to be in South Asia $(121,000)$ followed by SouthEast Asia $(111,000)$ and East Sub-Saharan Africa $(43,000)$.
Of interest, Papua New Guinea has one of the world's highest incidence rates of snakebites. The range of systemic and renal manifestations is well described in the minireview by Sgrignolli, Burdmann and their colleagues. Clearly, snakebite is an underestimated and ignored public health problem that causes considerable illness, death, and socioeconomic hardship to poor populations living in rural tropical regions of the globe. It is likely to be an additional cause of AKI and possibly CKD in the tropics along with poverty, infections and the growing impact of globalization. 